\title{
Patient Satisfaction with Athletic Trainers Working in a Physician Practice Setting
}

Nathaniel P. Acree, MA, LAT, ATC*; Forrest Q. Pecha, MS, LAT, ATC*; Joshua B. Lavigne, MS, LAT, ATC+; Esther C. Nolton, MEd, LAT, ATC, CSCS

*St. Luke’s Sports Medicine, Boise, ID; ${ }^{\dagger}$ Mid-Columbia Medical Center, The Dalles, OR; $\ddagger$ George Mason University, Fairfax Virginia

\section{Full Citation}

Acree NP, Pecha FQ, Lavinge JB, Nolton EC. Patient satisfaction with athletic trainers working in a physician practice setting. Clin Pract Athl Train. 2020;3(1):9-10.

https://doi.org/10.31622/2020/0003.4.

Presented at the $3^{\text {rd }}$ Annual Athletic Trainers in the Physician Practice Society Meeting and Conference, Columbia South Carolina. February 28-29, 2020

\section{ABSTRACT}

Background: Recent changes in healthcare administration via the introduction of the Triple Aim by the Institute of Healthcare Improvement have challenged healthcare institutions to improve the efficiency and effectiveness with which services are provided, while also enhancing patient experience. These changes have facilitated the hiring of clinical support staff from varying backgrounds with the aim of ensuring the goals of the triple aim are met within the clinical environment. Recently orthopedic practices have begun to include certified athletic trainers in the healthcare delivery team due to their advanced base of musculoskeletal knowledge. Previous literature has observed increased efficiency and revenue in physician practices where certified athletic trainers (ATs) are included in the healthcare team. However patient satisfaction with certified athletic trainers as healthcare providers in a physician practice is yet to be measured.

Methods: Design: Cross-sectional, descriptive. Setting: Physician clinic. Participants: New patients (NP) and guardians of minors who are NP presenting for evaluation in a primary care sports medicine practice. Intervention: A 10-item survey consisting of six-point Likert-scale items was developed in order to assess patient satisfaction with ATs in the domains of interpersonal care, technical care and global satisfaction within a physician practice setting. The survey was offered during a 23-month period to new patients in a physician clinic when ATs were involved with healthcare delivery during the initial encounter. Responses were collected via an electronic platform. Descriptive statistics were calculated, and mean scores were calculated for each Likert scale item and domain.

Results: A total of 186 completed surveys were analyzed. Mean score and standard deviation were: $M=5.76$ for interpersonal care, $M=5.78$ for technical care, and $M=5.81$ for global satisfaction.

Conclusion: In this study among new patients presenting for musculoskeletal care in an orthopedic physician clinic, participants reported high satisfaction with the technical, interpersonal, and overall care provided by athletic trainers. ATs may be an asset to the orthopedic physician practice with regard to patient satisfaction within the model utilized at study sites.

\section{Correspondence}

Forest Pecha, St. Luke's Plaza-Central Plaza, 720 Park Blvd. Suite 115, Boise, ID 83789

Email: fpecha@slhs.org

\section{REFERENCES}

1. Molinari C. Does the accountable care act aim to promote quality, health, and control costs or has it missed the mark? Comment on "health system reform in the united states." Int J of Health Policy Manag. 2014;2(2):97- 
99.

https://doi.org/10.15171/iihpm.2014.23.

2. Berwick $D$, Nolan $T$, Whittington J. The triple aim: Care, health, and cost. Health Aff.

2008;3:759-769.

https://doi.org/10.1377/hlthaff.27.3.759.

3. Berg G, Crowe R, Nyberg S, Burdsal C. Trauma patient satisfaction with physician assistants : Testing a structural equation model. JAAPA. 201 2;25(5):42-51. https://doi.org/10.1097/01720610$201205000-00008$.

4. Day CS, Boden SD, Knott PT, O'Rourke NC, Yang BW. Musculoskeletal workforce needs: Are physician assistants and nurse practitioners the solution? AOA critical issues. J Bone Joint Surg AM. 2016;98(11):e46. https://doi.org/10.2106/JBJS.15.00950.

5. Pecha FQ, Nicolello TS, Xerogeanes JW, Karas S, Labib SA. Patient perceptions of athletic trainers and orthopaedic medical residents as primary clinical support staff in sports medicine practice: a randomized, double-blinded prospective survey. J Allied Health. 2015;44(4):225-228. 